\title{
Relationship of Senior Perceptions of the Familiarization to the School Environment and Peer Social Support with Bullying of Juniors
}

\author{
Siti Wulan Sari ${ }^{1}$, Firman ${ }^{1}$, Riska Ahmad ${ }^{1}$ \\ ${ }^{1}$ Universitas Negeri Padang \\ *Corresponding author, e-mail: wulansarisiti12@gmail.com
}

\begin{abstract}
Senior students bullying juniors is one of the problems related to senior perceptionsof the familiarization to the school environment and peer social support, and the purpose of this study was to reveal relationship between these variables. This study uses a correlational method and has a sample of 202 students, who were found using techniques Proportional Random Sampling. Data were collected using a scale measuring senior perceptionsof the familiarization to the school environment ( 31 valid items $=0.914)$, a scale measuring peer social support ( 29 valid items $=0.873$ ), and scale measuringbullying to junior (29 items valid $=0.902$ ). Data were analyzed by multiple regression, and the results showed a correlation coefficient $R=0.089$ and $p=0.00(p>0.05)$. The results showed that there was a negative and significant relationship between senior perceptions of familiarization to the school environment and peer social support with bullying to juniors.
\end{abstract}

Keywords: Senior Perceptions of Familiarization to the School Environment, Peer Social Support, Bullying of juniors

How to Cite: Sari, S. W., Firman, F., \& Ahmad, R. (2019). Relationship of Senior Perceptions of the Familiarization to the School Environment and Peer Social Support with Bullying of Juniors. International Journal of Research in Counseling and Education, 3(2), 89-94.

\section{Introduction}

At present,there are various problems are occurring in the world of education in Indonesia. One problem which is quite widespread recently is the case of bullying among fellow students, which is occurring physically and also psychologically. Astuti (2008) argues that bullyingis a desire to hurt, and that this desire is shown with actions, which can cause a person to suffer. This action is carried out directly by a person or group that is stronger, irresponsible, and the action is usually repetitive, and carried out with a feeling of pleasure. Santrock (2007) reported that there are six issues of violence that occur in the educational environment that have shown very alarming numbers, including results which found that $16 \%$ of final grade students said that they had been threatened with weapons in school, and $7 \%$ had been verbally abused and physically threatened by other students. Firman and Nurmina (2018) there were $44 \%$ of teenagers who stated that the acts of violence they did were caused by their peers.

Based on findings by the North Sumatra KPAI, in 2016 there were 49 cases of students who were victims of bullying, and among these 49 cases there were 58 perpetrators of bullying. Some of thisbullying also occurs in the SMA Negeri 1 Kisaran. Based on information gained from interviews with BK teachers on 7 September 2016, there were fights between students of class X and XI students of SMA Negeri 1 Kisaran. Following this, some students developed bruises. Many students used objects, such as stones or wooden items, as an outlet during fights. Due to this incident, many students were afraid to attend school for a while, and learning could not be conducted due to this. The fights began with senior students taunting juniors during their familiarization of the school environment, and seniors also showed their power by telling juniors what they wanted.Seniors also implemented a program to familiarization the school environment using physical violence.

After interviews with several students on 27 September 2016, it was revealed that students thought the events that took place were a tradition by SMA Negeri 1 Kisaran students, and were passed from generation to generation. The tradition the juniors performed included marching and standing in the hot sun, 
carrying out orders to perform activities in accordance with senior wishes, even though these activities were seen as violating the norm. Some students think the treatment of juniors whilst they are gaining familiarization of the school environment is a way for seniors to get revenge for what they had to do during this time. Some seniors agree a plan of revenge treatment beforehand, and feel the revenge behavior they give to the junior is a necessity and is supported by other friends. If they do not give revenge they are seen as weak or timid. Based on the above description, the bullying that occurs in SMA Negeri 1 Kisaran is assumed to be derived from students' perception of the familiarization to the school environment and peer support.

Based on information from BK teachers, some students verbally bully others, for example by mocking or insulting their friends. Some students also carry out social bullying,such as isolating and picking on friends. Some students also carry out physical bullying, such as pushing, hitting, and kicking, which means there are frequent fights between students. Several students have found that a number of factors can influence the occurrence of bullying.Astuti (2008) argues that the causes of bullying behaviours are: (a) class differences (seniority), economy, religion, gender, ethnicity or race; (b) senior traditions; (c) families that are not harmonious; (d) school situations which is not harmonious, or are discriminatory; (e) the character of individuals/groups, such as the individual wanting to increase their popularity amongpeers; and (f) perceptions of the value of the wrong behavior for the victim. Firman (in Firman \& Karneli, 2018) explains that acts of violence are sometimes caused by small problems, such as misunderstandings, disrespect, and disputes,but they can end in assault, the destruction of private and public property facilities, and even murder.

Familiarization of the School Environment is an activity which occurs when students enter the school and begin to adjust and recognize the new environment that they are entering. Based Permendikbud No. 18 (2016)suggests that the process of this is to become familiar with the school's programs, facilities and infrastructure, and ways of learning, which can help to plant the concept of self-familiarization, and the initial formation of school culture. Minister of Education and Culture No. 18 (2016)states that the purpose of Familiarization to the School Environmentis: (1) to recognize students' self-potential; (2) to help students adapt to the school environment and its surroundings; (3) to develop motivation, enthusiasm, and effective learning methods as new students; (4) develop positive interactions between students and other school residents; and (5) foster positive behavior.

The process of students' Familiarization to the School Environment can lead to certain perceptions in students. Suharman (2005) suggests that perception is a series of information processing, a process of interpretation, or interpreting information obtained through sense tools. Firman, Sano, and Purwanti (2013) suggested that perception is a process of observation,organizing, interpreting, andassessment of the stimuli. Daharnis, Sukmawati, and Azhar (2013) suggested that perception is a judgment given by a person to a particular object or event. If seniors process stimuli about the familiarization of the school environment in a positive manner then it is expected that they will have a positive perception of the familiarization of the school environment. But if seniors process stimuli about the familiarization of the school environment in a negative way then it is expected that seniors will have a negative perception of the familiarization of the school environment. The research referred to in this study shows a good senior perception of the familiarization of the school environment they have experienced.

In addition to the perception of the familiarization of the school environment,another factor that influencesbullyingis peer social support. Sarafino (2006) suggests that social support can be interpreted as comfort, attention, or assistance received by individuals from others. Sarason (in Baron \& Byne, 2005) suggests that social support is the physical and psychological comfort provided by others. In research by Mead, Hilton, and Curtis (in Solomon, 2004) it is stated that peer social support is a system for giving and receiving assistance,founded on the key principles of respect, shared responsibility, and beneficial mutual agreement. Research by Meilinda (2013) suggests that if students are already bound in a group they will tend to follow what the group wants, because they only want to gain recognition from their group. This is because students want their presence to be recognized as part of the student community in general, and especially as a part of the peer group. Generally, peers are the source of the influence for student behavior. In relation to bullying with peer social support, it can be concluded that if seniors process stimuli about peer social support positively, then they are expected not to bully others. But if the senior processes stimuli about peer social support negatively, then the senior is likely to bully others.

The objectives of this study are as follows: 1) to describebullyingto juniors; 2) to describe senior perceptions of familiarization to the school environment; 3 ) to describe peer social support; 4) to examine the relationship between senior perceptions of the familiarization of the school environment with bullyingto juniors;5) to examine the relationship between peer social support with bullyingto juniors;6) to examine the relationship between senior perceptions of familiarization to the school environment and peer social support with bullyingof juniors. 
Method

This study uses a correlational method and has a sample of 202 students, found using techniques Proportional Random Sampling. Data were collected using a scale measuring senior perceptions of the familiarization to the school environment (31 valid items, $\alpha=0.914$ ), a scale measuring peer social support (29 valid items, $\alpha=0.873$ ), and scale measuring bullying to junior (29 items valid, $\alpha=0.902$ ). Data were collected and analyzed by multiple regression using the SPSS version 20.0.

\section{Results and Discussion}

The negative relationship between senior perceptions of the familiarization to the school environment and peer social support with bullying to juniors was both partially (each variable) and simultaneously (both variables) significant. This is indicated by a significant 0.00 less than 0.05 . The results of the regression coefficient between senior perceptions of the familiarization of the school environment and peer social support with bullying to juniors are individually and collectively summarized in Figure 1, which also looks at the relationships between variables. The highest relationship found is between all 3 variables $\left(\mathrm{X}_{1}\right.$ and $\mathrm{X}_{2}$ affecting $\mathrm{Y}$ ).

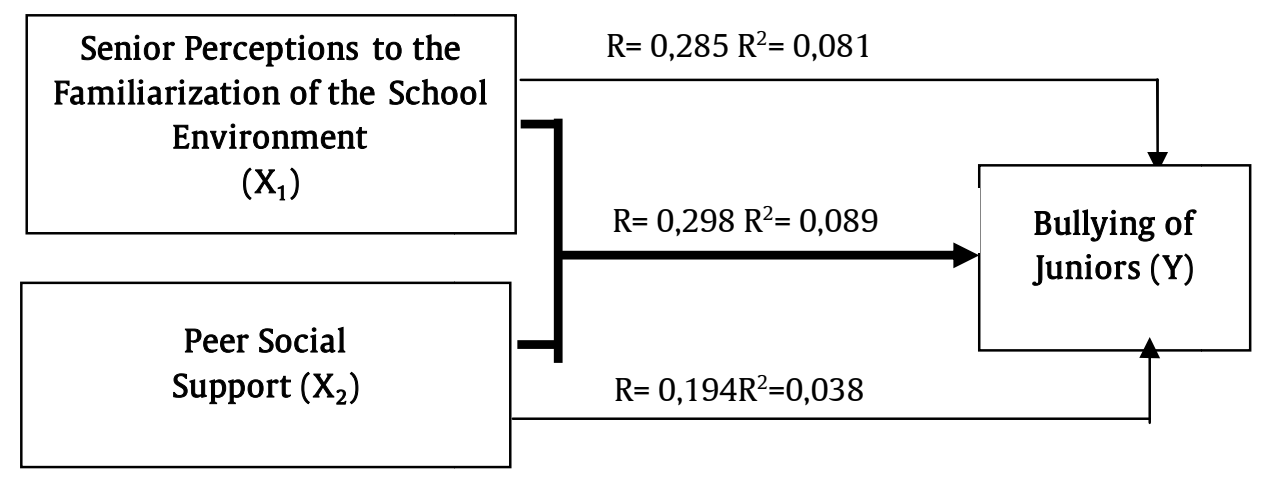

Figure 1: The relationship between $\mathrm{X}_{1}$ and $\mathrm{X}_{2}$ with $\mathrm{Y}$

Description:

$\mathrm{r} \quad$ : regression coefficient

$\mathrm{R}^{2} \quad$ : influence / contribution

\section{Discussion}

1. Senior Perceptions of the Familiarization to the School Environments

Overall, a good picture of senior perception of the familiarization to the school environment can be seen from the findings of this study.Of the sample of 202 students, it was found that most of the perception of senior familiarization of the school environment was in the positive category, with the highest score being 146 and the lowest score being 78 . The total score obtained was 22468 with an average score of 111,23 , percentage of $72 \%$, and a standard deviation of 14.29 .

This positive result can be seen from the senior recognition indicators regarding the understanding of the school environment, and the senior interpretation of the familiarization of the school environment, both of which were in the positive category. Scores for senior perception of the familiarization to the school environment were $15.34 \%$ in the very positive category, $64.85 \%$ in the positive category, and $1.80 \%$ in the fairly positive category. Based on the results of the BK teacher research, all of these categories need attention, not just the positive category. However, there were 31 students (out of 202) that were included in the very positive category. Therefore, BK services need to be improved to be able to change the senior perceptions that are wrong. BK teachers can provide services to students which cover topics such as school discipline and courtesy.

Amalia (2010) states that the experiences that occur in students from the perceptions of students to do the bullying. Students who have a positive perspective on the familiarization of their school environment means that students already know and understand the purpose of this familiarization, which can reduce the occurrence of bullying. 
2. Peer Social Support

Overall, it can be seen from the findings in the study that,with a sample of 202 students, it was found that peer social support was scored as highly positive. The highest score of peer social support was 142 , and the lowest score was 73 . The total score obtained was 22578 with an average score of 112 , percentage of $77 \%$, and a standard deviation of 12.985 .

This can be seen from the indicators of emotional support, instrumental support, and informative support, each of which is in the high category. Peer social support scores were generally positive, with $23.26 \%$ scoring in the very high category, $62.37 \%$ in the high category, and $14.35 \%$ in the fairly high category. Based on the results of the BK teacher research, all of these categories need attention, not just the high category. However, there were 29 students in the fairly high category, so it is necessary for BK services to be able to increase positive peer social support. BK teachers can provide services to students which cover topics such as fostering good relations with peers, and social ethics.

Zastrow and Ashman (2011)found that some important roles of peers are that students with friends give each other emotional support, and provide important information that can be used as a reference in comparing their beliefs, values, attitudes, and abilities with other students. This means that peers can provide various forms of positive social support for achieving goals. Furthermore,Sarafino (2006) emphasizes that emotional support given from peers has a very important role. This is because this form of emotional support aims to provide a feeling of comfort, safety, love, and happiness to the individual.

\section{Bullyingof Juniors}

Overall, it can be seen from the findings that, with a sample of 202 students, it was found most of the bullyingto juniors are in the low category, with with the highest score being 132 and the lowest score being 32 . The total score obtained is 12803 , with an average score of 63.38 , a percentage of $44 \%$, and a standard deviation of 15.85 .

This is seen from the indicators of physical violence, verbal violence, and non-verbal violence, all of which were in the low category. Physical violence can be described as hurting a limb, locking someone in a room, forcing objects belonging to someone else, damaging someone else's property; verbal violence can be described as saying something rude, insulting, threatening, or humiliating, and calling someone a bad name, scolding them, or giving orders; non-verbal violence means being cynical, or displaying unpleasant facial expressions. The scores of bullyingof juniors found that $21.78 \%$ was in the very low category, $63.86 \%$ was in the low category, $9.90 \%$ was in the medium category, $2.97 \%$ was in the high category, and $1.48 \%$ was in the very high category.

Astuti (2008) explains that bullying behaviors occur due to: (a) class differences (seniority), economy, religion, gender, ethnicity or racism; (b) the traditions of seniority; (c) families that are not harmonious; (d) school situations that are not harmonious, or are discriminatory; (e) individual/group characters, such as wanting to increase popularity amongpeers; and (f) incorrect perceptionsof victims' behavior. The results of the Sejiwa (2008) study also show thatverbal bullying and related bullying types were in the high category, with a percentage of $67.9 \%$. Wiyani (2012) stated that violence in junior high schools was seen in the top three areas, namely; Yogyakarta, with $77.5 \%$ acknowledging violence and $22.5 \%$ acknowledging the absence of violence; Surabaya, with $59.8 \%$ violence; and Jakarta with $61.1 \%$ violence. Bullies want to have more power than their peers so that they can manage weaker friends. The culture of bullyingcontinues to occur among students because of seniority, solidarity, and wanting to be accepted in their social group. Bullyingbehavior can have a negative impact on victims, such as fear, inferiority, worthlessness, depression, stress, and these behaviours can even convince an individual to attempt suicide.

\section{Relationship of Senior Perception of the Familiarization to the School Environment with Bullyingof Juniors}

The results of the study show that there is a significant negative relationship between senior perceptions of familiarization to the school environment with bullyingto juniors, and that this perception of familiarization can affect bullying of juniors by $8.1 \%$. The results of this study are supported by the opinion of Amalia (2010)who explains that the formalization experience forms perceptions of students about bullying.

Graye (2008) states that perception is a process of giving meaning to what is seen and felt. Suharman (2005) argues that perception is a series of either information processing, a process of interpreting, or interpreting information obtained through sensory devices. Beane (2008)stated that bullyingis an aggressive behavior which is intentional, painful, and carried out repeatedly. 
5. Relationship of Peer Social Support with Bullyingof Juniors

The results of the study showed that there was a significant negative relationship between peer social support with bullying of juniors, and that peer social support affects bullying of juniors by $3.8 \%$.

The results of this study are supported by Nation, Vieno, Perkins, and Santinello, (2007) who stated that bullying behavior is also caused by peer pressure and the need to be accepted in the group. Usman (2013) states that peer groups are a group of friends who have a strong emotional bond, and peer groups allow for students to interact, socialize, and exchange ideas. They also allow individuals to experience changes and adaptation, and development in their personal social life.

\section{The Relationship of Senior Perception of Familiarization to the School Environment and Peer Social} Support with Bullyingof Juniors

The results showed that there was a significant negative relationship between senior perception of the familiarization to the school environment and peer social support with bullying of junior students. Based on these results it was found that seniors who have a positive perception of the familiarization to the school environment and peer social support, which together contributes to bullying of juniors by $8.9 \%$. Astuti (2008) explains that bullying behavior can occur due to: (a) class differences (seniority); differences in economy, religion, gender, ethnicity or race; (b) tradition of seniority; (c) families that are not harmonious; (d) a non-harmonious or discriminatory school situation; (e) individual/group character, such as wanting to increase their popularity; and (f) the wrong perception of the victim's behavior.

Research by Amalia (2010) states that the experiences students have form their perceptions of students who bully. Nation, Vieno, Perkins, and Santinello (2007) state that bullying behavior is also caused by peer pressure and the need to be accepted in the group. Peer groups are a group of friends who have a strong emotional bond, they allow for students to interact, socialize, and exchange ideas.They also allow individuals to experience change and development in their social and personal lives. Flora (2014) suggested that bullying in Medan 12 High School was not only between senior students and their younger siblings, but also between peers. Bullying isnot just happening because its perception is wrong with the familiarization of the school environment and there is a lack of social peer support, but there are still many other factors that can influence it. The results of the Sejiwa (2008) study also show that verbal bullying is in the high category, with a percentage of $67.9 \%$. Wiyani (2012) stated that violence in junior high schools was seen in the top three areas, namely; Yogyakarta, with $77.5 \%$ acknowledging violence and $22.5 \%$ acknowledging the absence of violence; Surabaya, with $59.8 \%$ violence; and Jakarta with 61.1\%violence.Marjohan, Syahniar, and Zaimah (2014) suggest that bullying behavior is in the moderate category, with the highest student score of behavior bullying at 154, and student scores on bullying behavior as low as 134. The tendency of bullying behavior to occur can still be said to be quite safe and controlled, when students commit acts of violence against peers in reasonable conditions and not yet dangerous. Firman and Nurmina (2018) suggested that some of the factors causing violence and aggressiveness in adolescents are those such as silence because they had no friends, having pride in fighting, having a physical condition that was disappointing, unable to resist disappointment, and also feeling that there is nothing to be proud of, no place to tell, and that nobody can be trusted.

\section{Conclusion}

Based on the findings and discussion of the results of the study, then conclusions can be put forward, namely as follows: (1) overall, the total score obtained for the senior perceptions of the familiarization of school environment was 22468 with an average score of 111,23 , percentage of $72 \%$, and a standard deviation of 14.29. Based on these results it can be interpreted that, overall, the average achievement scores of senior perception of the familiarization of the school environment was in the positive category; (2) overall, the total score obtained for peer social support was 22578 , with an average score of 112 , percentage of $77 \%$, and a standard deviation of 12,985 . Based on these results, it can be interpreted that the achievement score of the average peer social support was positive andin the high category; (3) overall, the total score of bullying of juniors obtained was 12803 , with an average score of 63.38 , a percentage of $44 \%$, and a standard deviation of 15.85. Based on these results, it can be interpreted that the average achievement scores of bullying to juniors was in the low category; (4) there was a significant negative relationship between senior perceptions of the school environment with bullying of juniors. Based on these resultssenior perceptionsof the familiarization to the school environment contributed bullying of juniorsby 8.1\%; (5) there was a significant negative relationship between peer social support with bullying of juniors. Based on these results it was found that peer social support contributed to bullying of juniors by 3.8\%; (6) there was a significant negative relationship between senior perceptions of the familiarization to the school environment and peer social support with bullying of juniors. Based on these results it was found that seniors have a positive perception of the familiarization of the school environment and social support from peers, which together contributes to bullying to juniors by $8.9 \%$. 


\section{References}

Amalia, D. (2010). Hubungan Persepsi tentang Bullying dengan Intensi Melakukan Bullying Siswa SMA Negeri 82.

Astuti, R. P. (2008). Meredam Bullying (3 Cara Efektif Mengatasi Kekerasan pada Anak). Jakarta: Grasindo.

Baron, R. A., \& Byne, D. (2005). Psikologi Sosial. Jilid 2. (Ratna Djuwita, Ed.) (Kesepuluh). Jakarta: Erlangga.

Beane, A. L. (2008). Protect Your Child From Bullying. San Fransisco: Jossey-Bass.

Daharnis., Sukmawati, I., \& Azhar, S. K. (2013). Persepsi Siswa tentang Layanan Informasi Kesehatan Reproduksi Remaja yang Diberikan Guru BK SMAN 1 Kubung, 2, 146-150.

Firman, F., \& Karneli, Y. (2018). Panduan Layanan Konseling Kelompok dalam Penurunan Agresivitas Remaja Berasal dari Sekolah Menengah Atas, (October).

Firman, Sano, A., \& Purwanti, W. (2013). Hubungan Persepsi Siswa terhadap Pelaksanaan Asas Kerahasiaan oleh Guru BK dengan Minat Siswa untuk Mengikuti Konseling Perorangan, 2, 347-353.

Firman \& Nurmina. (2018). Upaya Sekolah dalam Penanggulangan Agresivitas Remaja di SMA Propinsi Matera Barat, (Oktober).

Flora, R. (2014). Mengurangi Perilaku Bullying Kelas X-4 Melalui Pemberian Layanan Bimbingan Kelompok Teknik Role Playing di SMA Negeri 12 Medan.

Graye, R. (2008). Performance and Self Perception, 2.

Marjohan., Syahniar., \& Zaimah, R. D. (2014). Kontribusi Pengasuhan Orangtua dan Self-Esteem terhadap Perilaku Bullying, 3(4).

Meilinda, E. (2013). Hubungan antara Penerimaan Diri dan Konformitas terhadap Intensi Merokok pada Remaja di SMK Istiqomah Muhammadiyah 4 Samarinda. Psikologi, 1.

Nation, M., Vieno, A., Perkins, D. D., \& Santinello, M. (2007). Bullying in School and Adolescent Sense of Empowerment: an Analysis of Relationship with Parent, Friends, and Teacher. Community \& Applied Social Psychology. https://doi.org/10.1002/casp

Permendikbud. (2016). Pengenalan Lingkungan Sekolah Bagi Siswa Baru. Jakarta: Permendikbud.

Santrock, J. W. (2007). Perkembangan Anak (1st ed.). Jakarta: Erlangga.

Sarafino, E. P. (2006). Health Pscychology: Biopsychosocial Interactions(Fifth). USA: John Wiley \& Sons.

Sejiwa. (2008). Bullying: Mengatasi Kekerasan di Sekolah dan Lingkungan. Jakarta: Grasindo.

Solomon, P. (2004). Peer Support/Peer provided Services Underling Processes, Benefits, and Critical Ingredients.

Suharman. (2005). Psikologi Kognitif. Jakarta: Aneka Karyacipta.

Usman, H. (2013). Manajemen Teori, Praktik, dan Riset Pendidikan (Keempat). Jakarta Timur: Bumi Aksara.

Wiyani, N. (2012). Save Our Children from School Bullying. Yogyakarta: Ar-Ruzz Media.

Zastrow, C. H., \& Ashman, K. (2011). Understanding Human Behavior and Social Environtment. USA: Library of Congress Control. 